\title{
EU-Compatible State Measures and Member States Interests in Public Services: Lessons from the Case of Hungary ${ }^{1}$
}

\author{
Tamás M. Horváth \\ MTA-DE Public Service Research Group, Hungary \\ horvath.m.tamas@law.unideb.hu \\ Ildikó Bartha \\ MTA-DE Public Service Research Group, Hungary \\ bartha.ildiko@law.unideb.hu
}

\section{ABSTRACT}

National interest, also as a critisism against the pradigm of New Public Management (NPM), is very much emphasised nowadays in public policies, even in sector ones. This article is about a removal from the classical meaning of general (public) interest to that new approach represented by certain EU Member States and the reasons behind. Our analysis focuses on contextual motives and impacts of these changes illustrated by the Hungarian case. The result shows that the market of public utility services has already been influenced by direct political considerations. Our findings indicate that these understandings for legitimate influence on EU market rules can also be derived from the legal framework itself. Measures examined in the paper run completely counter to the spirit of the original intention of the founders of the integration, and recent changes in EU law do not seem to raise unavoidable obstacles to such cases. Lessons of this case may be relevant for other EU Member States as well, at least for those from the Central-European region.

Keywords: centralism, exclusive rights, non-regulative price cutting, public services, services of general economic interests (SGEI)

1 This article is a result of the project Reassessment of State Roles in Regulation of Services implemented by the MTA- DE Public Service Research Group, supported by the Hungarian Academy of Sciences under Grant No. 05216. 


\section{Introduction}

Centralization may be an answer on problems brought by crises like in the case of Greece (Tsekos T. N. and Triantafyllopoulou A., 2016) and Hungary, or on effects of political turn like in Poland (Białecki, I., Jakubowski, M., Wiśniewski, J., 2017) in 2010s. Our hypothesis is that both of the two directions originate in economic reasons. This thesis can partially be proved by applying an inductive method in this study. The recent Hungarian example in public utility service provision is about actual changes in the way as direct political actions' may influence the market. Lessons of this case may be relevant for other EU Member States as well, at least for those from the Central-European region. The authors evaluate these changes through the policy of administrative price cutting scrutinizing motives and reasons of measurements. Contextual issues are also important, because reorganizing ('reform-') strategies are not really built on evaluation logic of New Public Management (NPM). A national-value orientation and a very strong direct interest motivation are heavily involved. In the system of central influences, the meaning of evaluation is necessarily different than in the environment of liberalized market. Here it is much less based on actions of independent regulators, benchmarking or comparison when it comes to well-run undertakings.

It makes much difference whether sector policies and measures of EU Member States are non-liberal or still compatible with the internal market law of public services. However, borderlines are nowadays rather relative between these qualifications especially from the point of view of those Member States which are reluctant enough to follow the mainstream without criticism. Based on the examination of that particular case, our research question is that in what extent recent trends in national policies and regulations of public service provision are compatible with the requirements of the European Union from a legal and public policy perspective. Examples like the Hungarian case highlight the challenges and threats of recent understandings of state measures in services of general interests (SGEIs) at different intergovernmental levels in the 2010s. The present paper seeks to explore the international and domestic background for such trends and also evaluates, by analysing the relevant EU regulatory framework, the margin of discretion left to the Member States in this respect.

\section{Methods}

After the international credit crisis (2008) and a moderate sovereign debt crisis (in the decade of the 2000s) the former management structure of public services (Horváth, 2000) was questioned in Hungary. Social conflicts led to radicalism in politics. The effect on municipal activities and functions became very restrictive. Also as a response, the regulatory position of the state was enhanced, and central government preferences were greatly widened. In some European countries the crises have led to corrections in the competition policy of public services. In Greece, as a comparable case, municipal overspending had to be given up, with a turn to NPM-proposed alternative solutions 
of service delivery (Tsekos T. N. and Triantafyllopoulou A., 2016). This policy involves increasingly the roles of private actors either as investors or volunteers. In strong contrast, the Hungarian case is one showing a trend towards pure centralism. The Hungarian example shows that the market of public utility services has already been influenced by direct political considerations. In the meantime, public civil solutions and control are also rapidly neglected in welfare services, as it is also clear from the example of the education reforms in Poland (Białecki, l., Jakubowski, M., Wiśniewski, J., 2017). The Hungarian case may lead to a model of extensive state intervention.

The direct theoretical background of the paper is threefold. Firstly, country-specific ${ }^{2}$ but contextual crises studies are based on explanatory research (Hajnal, 2014; Hajnal and Rosta, 2016) of the present turn in the development of the country. Secondly, different concepts of 're-public' solutions have recently been used as explanatory variables like the concept of re-municipalisation (Hall, 2012; Pigeon et al., 2012, Water Remunicipalisation Tracker) and the re-emergence of municipal corporations (Wollmann and Marcou, 2010).In addition, the policy of Hungarian centralization model has been scrutinized in context by Horváth (2016) on this basis. Thirdly, the paper also examines the above process from the perspective of Member States' obligations under EU law as public services are subject to EU internal market rules and EU competition rules (Sauter, 2014).

There are a few methods being combined in this paper:

i) EU law, though it also uses terms evolved at national level (i. e. public utilities or/and public services), has a distinct conceptual framework (in details, see Szyszczak, 2017). The EU terminology is based on the categories of Services of General Economic Interest (SGEI), Services of General Interest (SGI), and Services of Social General Interest (SSGI) recently, together with emergence of the 'European Social Model' (European Commission 2006). The former (SGEI) is used in primary law texts, without being defined in the Treaty or in secondary legislation. However, in the case-law of the European Court of Justice (hereinafter ECJ) and EU Commission practice there is broad agreement that SGEI refers to services of an economic nature, with the Member States or the EU being subject to specific public service obligations (PSO) as compared to other economic activities by virtue of a general interest criterion. ${ }^{3}$ The term SGI, the closest EU law equivalent to the traditional notion of public services (Sauter 2014, 17), is also derived from the practice. It is broader than SGEl and covers both market and non-market services which the public authorities classify as being of general interest and subject to specific public service obligations (Bauby and Similie, 2016a).

ii) Although evaluation studies of public sector (Wollmann, 2003) and institutional reforms (Kuhlmann and Wollmann, 2011) at intergovernmental

2 Cf. Gajduschek, G., Horváth M., T., Jugovits, K., 2017.

3 See in particular the definition given by the ECJ in its judgments in cases C-179/90 Merci convenzionali porto di Genova, ECLI:EU:C:1991:464 and C-242/95 GT-Link, ECLI:EU:C:1997:376. 
levels are based on the reform rhetoric of NPM, in this case the question is to what extent this terminology may be used, because the orientation of changes is clearly beyond the motivations of public service performance.

iii) The relationship to the NPM paradigm is opposed heavily by the present Hungarian central government, ${ }^{4}$ which involves the denial of market-orientation in most of the public services and open competition for foreign investors. National interest is very much emphasised nowadays in public policies, even in sectoral ones. In addition, reform as terminology has been neglected in the rhetoric of the government since 2010. Official communication is instead built upon national community-based heuristic statements. It seems that at least voters have been convinced.

The domestic background and international context have been explored on the basis of participant observation and comparative analysis carried out as being involved in national company's $s^{5}$ urban service management projects and activities, and as a part of the research in other domestic and international projects. ${ }^{6}$ For Chapter 4.1 and 4.2, we also obtained data from a specific ECJ case-law database ${ }^{7}$ containing a thematic collection of all ECJ cases related to the EU Member States' public service provision legislation and administrative practice, as well as from a case study database resulting on field research and empirical data collection. ${ }^{8}$

\section{Results}

\subsection{Starting Conditions in Context}

The corporate government in the infrastructural sector came to the attention of the national-conservative Viktor Orbán's government ${ }^{9}$ very early after the election win in 2010 and its subsequent re-election in 2014. It obtained a two-thirds majority in both the Parliament and in most of the city assemblies. According to their narrative the former type of economic power was based on earlier political bargaining called privatization by liberals, who were leading supporters of the transformation process from the formal system transition (1990) to joining the European Union (2004). The nationalist government coalition, consisting of so-called national conservatives supplemented with Christian Democrats, differentiated from but supported by extremists, wanted to re-make originally long-terms contracts in order to change the players of the game.

4 For the Hungarian Government's approach, see the Magyary Zoltán Public Administration Development Programme (Mp 12.0), especially pp. 6-7, <https://magyaryprogram. kormany.hu/admin/download/a/15/50000/Magyary_kozig_fejlesztesi_program_2012_A4_ eng_\%283\%29.pdf>.

5 Budapest Urban Management Centre cPlc.

6 COST Action Local Public Sector Reforms (LocRef) WG I External (Post-)NPM Reforms (201316); MTA-DE Public Service Research Group ,Regulatory Tools for Local Public Services' project (2012-2017).

7 Non published database of the MTA-DE Public Service Research Group.

8 Case-study database of the same research group: <https://jog.unideb.hu/hu/node/191>.

9 Viktor Orbán is the Prime Minister of Hungary between 1998-2002, 2010-2018 and 2018 by now. This paper especially focuses on the period of 2010 s. 
The really specific context of the Hungarian case that Prime Minister Viktor Orbán argued on this issue in his campaign and by his general political attitude to the public was that foreign private companies had abused their dominant position by overcharging for their services. ${ }^{10}$ That was why the conservatives wanted to buy back shares of these companies. This was one of the key motivations for changing the political system (Hajnal, 2014) and market relations, including public services provision. The national-conservative ideology here paradoxically focuses on state-centred solutions for every conflicting social or economic issue. Market-orientation shifted to state-centred defence of socalled national interests.

In the background there is an economic logic linked to user charges. To understand the recent situation let us go back to the transformation process. From that time user charges became again an important element of public financial transfers (Horváth and Péteri, 2001). User charges are also forms of systemic financing mainly in public utility services. The long history of transition countries demonstrates that these sources may also be considered transfers depending on the decision regarding which level of government may collect them. In communist countries most urban services, like water and sewerage, central heating, and solid waste collection were free or the price was a symbolic payment involving social rental flats. Some services were subsidized centrally, particularly electricity and gas.

In the period of transformation giving these revenues 'back' to governments became a decision on financial transfers. This sector transition process was composed of several steps. Firstly, starting from 90 s prices were to be liberalized in the public sector. This was important even if the state enterprises were the only providers at the beginning. Secondly, conditions for competition had to be established. An emerging market was built up with privatization for these services parallel with the multiplying number of service providers. This was an opportunity to decide about the application of user charges.

In principle user charges are good for some different purposes of local government. These include covering costs and maximizing revenues, and they can act as an incentive for economical use. According to the theory (Bird, Ebel and Wallich, 1995) the importance of user charges is that municipalities can behave as service providers. It means that the correct (roughly marginal cost) price is achieved for public consumers. In the new situation the government politically criticized foreign providers to monopolize the definition of user charges. Additionally, after the elections quite a lot of criminal cases were created against top managers in public utility companies accusing them of political corruption.

However, on the basis of this radical political concept, there are quite a few arguments, based on pure economic interests, which seem to explain their

10 See especially Orbán's speech in Tusnádfürdő (Baile Tusnad, Romania, 26.07.2014) about his political programme. <http://www.kormany.hu/en/the-prime-minister/the-prime-minister-sspeeches/prime-minister-viktor-orban-s-speech-at-the-25th-balvanyos-summer-freeuniversity-and-student-camp>. 
motivation. First of all an easy explanation is shown by the national government with the support of consumer price indexes. It is illustrated in Figure 1 in the Annex. The interrupted line below (signified by the arrow also) is the level of total Consumer Price Index in Hungary between years of 2003-2012. The level of water pipe services, solid waste management and disposal, waste water treatment, central heating and warm water services are typically at a higher level continuously. The rise of prices is higher in these sectors than the actual inflation rate. As an exemption, an extreme increase in prices of central heating was compensated by the former government regime. However, others remained on the upper level when the nationalist government started its term from 2010. According to the official argument, utility companies, especially their foreign private owners, pulled out profits from households, that is to say, from 'the nation'.

Behind this argument there are critics of two different inherited basic scenarios in the ownership structure of public utility companies which had arisen by the 2000s. One is the model of formerly privatized companies. It was accused of uncontrolled monopolization by new government powers. The other model, i.e. companies remaining in municipal hands, was also criticized heavily because it was seen as affiliation the former government parties either at local or national levels.

As far as the first scenario is concerned, it was true that implemented solutions of privatization in the public utility sector were rather different. In order to properly understand this issue, let us turn to Bauby's and Similie's generalized classification (Bauby and Similie, 2014, p. 108). There are two basic specific contractual models on the extension of the private sector in public services. The traditional French legal practice is based on lease and concession contracts. The German model prefers corporative structures in which the operating assets are corporatized and where in the asset holding company the private providing company (the operator of the concession) is a minority shareholder at the same time. From the second half of 1990s the German model was followed in Hungary, with the difference being that not only operating but also core assets (pipelines, networking works) were corporatized in many situations. The importance of this kind of systemic failure was realized about fifteen years later when it became clear that multinational private companies have a strong position mainly in the situation when municipalities as local clients wanted to shift their contracts.

'Who is responsible for this situation?' The question was raised in the systemic turn from 2010, because the solution was against the basic legal regulation of the local government act of 1990, which was passed at the beginning of system transition. Core assets should have been kept in municipal ownership because marketing was prohibited by the law. There are different answers on the responsibility question from the government side, which are as follows:

i) Responsibility' of former governments. Privatization had been preferred by central governments for many terms before 2010. However, public utility assets had not yet been registered at all. Content of ownership was not 
defined earlier, especially during the long period of state socialism, where this kind of specification was not in question at all. So, the registry court registered memorandums of new private sector providing companies, without any questioning in many situations.

ii) City leaders' and politicians' 'responsibility', who had been in position at that time. The new government accused its predecessors of selling out assets consciously, following only their own interests.

iii) Foreign investors' 'responsibility'. According to the political rhetoric international professional companies wanted to obtain a monopoly in order to get extra-profit and only foreign interests were represented by them. It has been being emphasized by the government since 2010 that some of the West-European governments and German federal member states (Länder) are also shareholders in quite a few utility companies providing services in Hungarian cities and regional areas.

These above mentioned motives have been inspired by the policy of re-structuring in public service corporate sector during the era of the nationalist government since 2010.

\subsection{Public Services in the EU Integration}

As a general rule, EU internal market and competition rules apply to services of general economic interest as well, save where they fall under specific regulations or exceptional clauses of the EU Treaties. In this section, we will briefly outline the legal fundamentals relevant to SGEls including those provisions escaping them from the generally applicable market rules.

Before the adoption of the Single European Act (SEA) of 1986, the matter of public service provision was not at the heart of the European integration process. In line with the principle of subsidiarity under Article 5 of the Treaty of European Union (hereinafter TEU), a consensus have been reached between the Member States that each country has the competence to organize and finance its basic public services (Bauby, 2014, p. 99). It was based on the general idea to balance the EU interest in the free market with the national public interests, which means that public enterprises, state monopolies, special and exclusive rights as well as SGI are compatible with EU law to the extent that they involve proportionate restraints with regard to the internal market and competition rules (Sauter, 2014, pp. 20-21 and 41). This early economic compromise has been expressed in certain (and still existing) provisions dating back to the original Rome Treaty of 1957 (currently Articles 37, 93, 106 and 345 of the Treaty on Functioning of the European Union, hereinafter TFEU), as guarantees for safeguarding the interests linked to the provision of public services.

Article 106(1) TFEU generally states that public undertakings and those entrusted with special or exclusive rights are not exempted from EU competition rules. Article 106(2), however, lays down a derogatory regime for services of 
general economic interest (Bauby and Similie, 2016b), providing that these undertakings are subject to EU competition law provisions (that is Articles 101, 102 and 107 TFEU) only in so far as the application of such provisions does not obstruct the performance of their particular public service obligation.

Most cases concerning the EU competition rules and public services have been examined in the context of dominance abuse and state aid rules (Sauter, 2014, p. 75). Granting exclusive or special rights to an undertaking often generates the dominant position itself that is the precondition for unlawful conduct under Article 102 TFEU which, as Article 106(2) suggests, may nevertheless be saved by referring to the 'particular tasks assigned to them'. The legality of public monopolies and other entities (often operating as stateowned companies) enjoying exclusive or special rights is supported by the freedom of Member States to choose their system of property ownership, guaranteed by Article 345 TFEU (Sauter, 2014, p. 44). ${ }^{11}$

Most forms of state aid are in principle prohibited under Article 107(1), unless they are found to be compatible with the internal market because of their specific objectives under paragraphs (2) or (3) of the same provision. In the case of SGEl, however, public service obligation compensation (that is where the State pays aid to undertakings as a compensation for fulfilment of PSOs), under certain conditions (see judgment of the ECJ in case C-280/00 Altmark Trans, ECLI:EU:C:2003:415), does not qualify as state aid. In addition, non-economic SGI a priori fall outside the scope of Article 107 TFEU, since state aid rules only extend to services that qualify as economic activities (Sauter, 2014, p. 76).

Europeanization of Public Services. Although the above provisions had been incorporated into the founding Treaties in the very beginning of the European integration process, their role and significance have changed over time. The "Europeanization of public services" ${ }^{12}$ started only in the mid-eighties with the entry into force of the Single European Act. The SEA, together with the Commission's white paper on reforming the common market, set the objective of the creation of a single market by 31 December 1992. As the national markets in transport and energy have become integrated with this conception, public service obligations have been obstacles to market creation (Opinion of AG Colomer in case C-265/08 Federutility, ECLI:EU:C:2009:640; Рrosser 2005, 121). Thus, the process engaged by the SEA led to a progressive liberalisation, sector by sector (Bauby and Similie, 2016b). The case-law of the Commission and the ECJ also reflected this market-friendly attitude; provisions permitting special treatment for such services were interpreted narrowly and restrictively (Prosser, 2005, p. 12).

This free market orientation has been 'constitutionalised' in the Treaty of Maastricht, which set, by enacting a new clause (Art. 3a), "the adoption of an economic policy which is based [...] on the internal market [...] and conducted in accordance with the principle of an open market economy with free com-

11 The text of Articles 102, 106, 107 and 345 TFEU see Annex 1 below.

12 Term borrowed from Bauby and Similie (2016a, p. 27). 
petition" as a common goal for the EU and its Member States. The advocates of the public service model responded to the reform by campaigning for a Treaty amendment (and even for a distinct 'Charter of Public Services') to recognize more clearly the distinctive role of public services. (Prosser, 2005, p. 154).

These critical movements led to the first Commission Communication on services of general interest of 1996, which laid a particular emphasis on the social elements of public services as well as the limits of market forces (Prosser, 2005, p. 156). Then, the Treaty of Amsterdam has been amended by a new Article 16 of the Treaty of European Community (TEC) which, among the fundamental principles of the EU, reinforces the constitutional importance of the role and protection of SCEI obligations. As safeguarding public services is primarily the interests of the Member States, the provision can be seen as a confirmation of the Member States' traditional prerogatives and discretionary power in the organization of such services (Rusche, 2013, p. 102; Schweitzer, 2011, p. 55; Varju, 2013, p. 112).

Although the real legal relevance of that provision is questionable (Ross, 2000, p. 34), SGEls have been treated since then less as an obstacle to the completion of the internal market and more as an expression of citizenship rights and so of value in themselves (Prosser, 2005, pp. 172-174; Varju 2013, p. 112). This approach was also confirmed by the practice of the Commission and the ECJ, as well as by the adoption of The Charter of Fundamental Rights (in 2001) including a separate provision (Article 36) on right to access to SGEl.

The above process has assumed particular importance in the liberalization of specific sectors, especially in the field of utilities (Prosser, 2005, p. 174). Although market opening and access remained a central policy objective, other priorities were being also promoted. This 'paradigm shift' (Hancher and Larouche, 2011) is an important factor in explaining why the degree of liberalization varied from sector to sector. The liberalization was extensive (though not complete), for instance, in telecommunications, or electronic communications. The energy market, however, remained dominated by the presence of natural monopolies (dominant undertakings by the Member States), where the specific public service grounds (universal service obligation, security of supply, environmental concerns) gave the Member States more opportunities to derogate from market liberalization (Prosser, 2005, pp. 174 and 192-194; Hancher and Larouche, 2011).

Regulation of Public Services in the Social Europe. The "safeguarding" provision introduced by the Amsterdam Treaty (ex-Article 16 TEC, now Art. 14 TFEU) has been slightly (but importantly) modified by the Lisbon Treaty, with an express reference to the protection of national autonomy under Article 4 TEU. The new provision expressly pointed out the Member States' competence to provide, to commission and to fund such services. A Protocol on Services of General Interest (No. 26) was also added to the Treaties (TEU and TFEU). Reading Article 14 and the Protocol together, there is an even higher emphasis on national and local interests and a more state-centred approach seems 
to be applied to the protection of public service values. Moreover, the Charter of Fundamental rights including the right to access to SGEI became binding with equal effect to the Treaties by entering into force of the Lisbon Treaty in 2009.

The above provisions reflect a political signal from the authors of the Lisbon Treaty that there is a need for protection of SGEI and particular local interests attached to them against the efforts of liberalization (Rusche, 2013, p. 106; Krajewski, 2011, p. 186). In other words, the Lisbon Treaty consolidated the 'welfare autonomy' of Member States (Marćou, 2016, p. 14).

The process of Europeanisation of SGEl and the 'paradigm shift' outlined above in the context of the Treaty provisions was also manifested in the caselaw of the European Court of Justice and in the European Commission's soft law (and practice). The details of the relevant cases will be discussed below, however, we only summarize the main issues from SGEl jurisdiction.

Turning to secondary legislation and soft law, a similar process can be seen in the Commission's activity. The first SGEI Communication of 1996 was followed by several others ${ }^{13}$ in the first half of the last decade. These pieces of soft law reflect a shift in emphasis, giving support to the more radical reading of the current Article 14 TFEU. The link between SGI and European citizenship as an important contribution to the values of European life was highlighted in the Commission's communications, rather than seeing the former as obstacles to the completion of a competitive single market (Prosser, 2005, p. 163).

The Commission's legislative activity from the mid-2000s was largely influenced by the case-law of the ECJ. The leading decision is the Altmark judgment of 2003 in which the Court held that the discharge of PSO is not covered by Article 107(1) TFEU where it merely compensates the provider of a public service mission for the costs that arise due to the performance of the PSO and determined four cumulative criteria which have to be met for not qualifying public service compensation as state aid.

By declaring these group of financial compensation out of the realm of state aid concept, the Court, in essence, largely reduced the monitoring and decision-making competence of the Commission over national measures granting compensation for public services (Bauby and Similie, 2016b), as the judgment allows for a self-assessment by Member States of that issue. This means in fact, that Member States were left relatively free under the criteria defined by the Altmark judgment. In particular, the fourth condition (the option of using a benchmark as an alternative for a tendering procedure in order to ensure efficiency) leaves wide room for Member States discretion. Such an outcome of the judgment clearly follows from the above mentioned paradigm shift in the constitutional framework whereby the EU leaves the Member States free to organise the SGEI markets themselves (Vedder, 2013, p. 66).

13 See European Commission communications COM(2001)598, COM(2004)374. 


\section{Discussion: Back to the Nation States?}

\subsection{Nation-based Reorganization in the Corporate Sector}

There are three basic fields of corporate reorganization in the Hungarian public utility sector recently: (i) ownership, (ii) exclusive rights and burdens and (iii) user charges. Municipalities and the national government directly forced buying back shares of providing companies from foreign private investors. Acts passed by the Parliament supported this policy directly through re-defining and narrowing groups of authorized providers service by service. In further steps, consumers' fees were restricted for inhabitants by the central government via direct influence in the market of delivery services, neglecting any regular tools of regulatory authorities.

i) Re-distribution of influence on ownership in the public utility sector. At the very beginning policies of municipalities, mainly of cities, shifted. In the overwhelming majority of cases, party affiliation was the same as that at the central government level. The performance of utility companies was criticised heavily here. The main argument arose as follows:

- high level of consumer fees in comparison,

- little contribution to local municipal revenues,

- dirty businesses,

- liability problems in public contracts

As answers, if municipalities sold at least partly their shares earlier, then they wanted to buy back providing companies and the exclusive rights on the delivery of particular services from private owners and managing companies. In cases of companies remaining in the hands of local governments, changes of corporate management were forced, leading to the establishment of general asset holding companies.

In the countryside, amalgamation of service providers occurred under the umbrella of municipally or centrally owned companies. Private investors were forced by the government with sector laws on different public services (especially in the field of water, gas and electricity supply or waste management) to sell their majority shares. For instance, as a result the number of providers decreased to 20\% from 2007 to 2014 in solid waste management. This has meant the integration of delivery service, in addition to change in the identity of the owners.

ii) Exclusive rights and special taxes. All of the new integrated providers obtained exclusive rights to provide particular services of general economic interests. This action is allowed by the secondary law of the EU. However, in the second phase of re-structuring, from 2012, several measures were undertaken by the national government to centralise profits from the energy, water, waste and other (funeral, park maintenance, chimney sweeping services) public utility sectors. 
This is done by levying special central taxes. Providers are now burdened with tax levied on public utility networks on the basis of their length. There is an exemption if the company is 100 percent publically owned. Discrimination has been raised in several legal procedures, however so far these have not been obstacles for the implementation of obligations. Additionally, even municipality-owned providers are burdened with other taxes, like income tax on waste management (this burden is also placed upon energy companies), taxes on unbuilt sites, fees on waste disposal in landfills, etc. In these cases the aim of the central government must have been to centralize business profits, especially not to leave them to municipal owners.

iii) User charges. The third phase of the reorganization in the service providing environment started from the beginning of 2013. From that time the central government has in four waves decreased consumer fees of particular utility services for inhabitant users. The political impact of this measure was clearly targeted in the government's strategy. In the first round, from January 2013 to 2014, electricity, gas and district heating fees have been gradually reduced to $75,44 \%, 74,80$ and $77,34 \%$ of the original price (established in 2012 December) of these services respectively. Then, from July 2013, liquid waste, solid waste, chimney sweeping and drinking water fees have been cut to $90 \%$ (in the case of solid waste $93,78 \%$ ) as compared to the price level of January 2012, April 2012, December 2012 and January 2013. After 2014, the level of these utility fees has remained constant thus not following the decrease of energy prices on the world market.

Centrally ordered cut on tariffs of utility services was about a nominal 10-25 per cent. A direct regulation of user charges for utility services became a major focus of the Orbán government and one of its key policy aims. This popular policy ('decrease burdens of families') was also placed in the centre of the political agenda in order to win the 2014 elections. It was a very successful strategy from the nationalist right wing point of view in the general, EU and subsequent local elections. The political (and not policy) motivation is emphasized by the government in the way that the calculations for the savings of households are prescribed to be put on the official receipt sent out on a monthly basis. Even a coloured (!) background of this notice is obliged to be included by the law in order to make sure customers pay enough attention to the effect of the government intervention.

Now let us see the effect of the cuts. Annex 2 shows the change of customer price indexes in recent years. The reduction is lower in each item than is prescribed by the law. This must be explained by reference to the cut on inhabitants only. Legal persons and undertakings have to pay full price. Nevertheless, their rate is higher now than the original inhabitants' charge before the direct regulation. In contrast, the fact is that energy prices decreased on the world market. In addition, different supplementary services (change of water meter, controls etc.) are more expensive, especially for non-residents. Consequently, the level of service provision is not rising or effectively worse than it was before. Providers try to escape from barriers of regulation. For 
instance, waste collection companies went back to the phase of a fixed frequency-based monthly charge from the existing quantity-based regime.

A clear evaluation of these input changes is shown by the fact that a third of existing solid waste management companies (171 in 2016) are working with a loss as a result of the described management policy.

\subsection{Direct Impacts}

The whole process of (re-)transformation in the public utility sector can be summarized as follows. The central government is extremely active in making rules for the economic environment of public utility service provision in this country. Since 2010, several measures have been undertaken to centralise profits from the energy, water, waste and other (funeral, park maintenance, chimney sweeping services) public utility sectors. Providers are now burdened with a central tax levied on public utility networks. The general cut in prices of user charges is supplementary and a new supervisory fee has been introduced for an administrative regulatory authority. Additionally, municipal utilities were exempted from some of the taxes, but this is no longer the case and the financial burden for municipal utilities is now heavier, especially for the central government. Although maintenance costs are covered by user charges, tariffs are however defined by Parliament and the government. As far as working capital investments are concerned, because the company is fully owned by municipalities or the state, paradoxically, national and European Union grants were more easily available because no further guarantee was needed for keeping the new utilities in public hands. The aim of the national government seems to shift public utilities to non-profit-making services. In this case, neither the role of municipalities nor the providers' presumable counter-interest has been specified. This process must have an effect on the public service level in a medium term perspective. The model of the process is shown by Figure 1 on the next page. 
Figure 1. A logic framework for the recent Hungarian centralization process

\section{1) amalgamation and transformation are forced by sector laws}

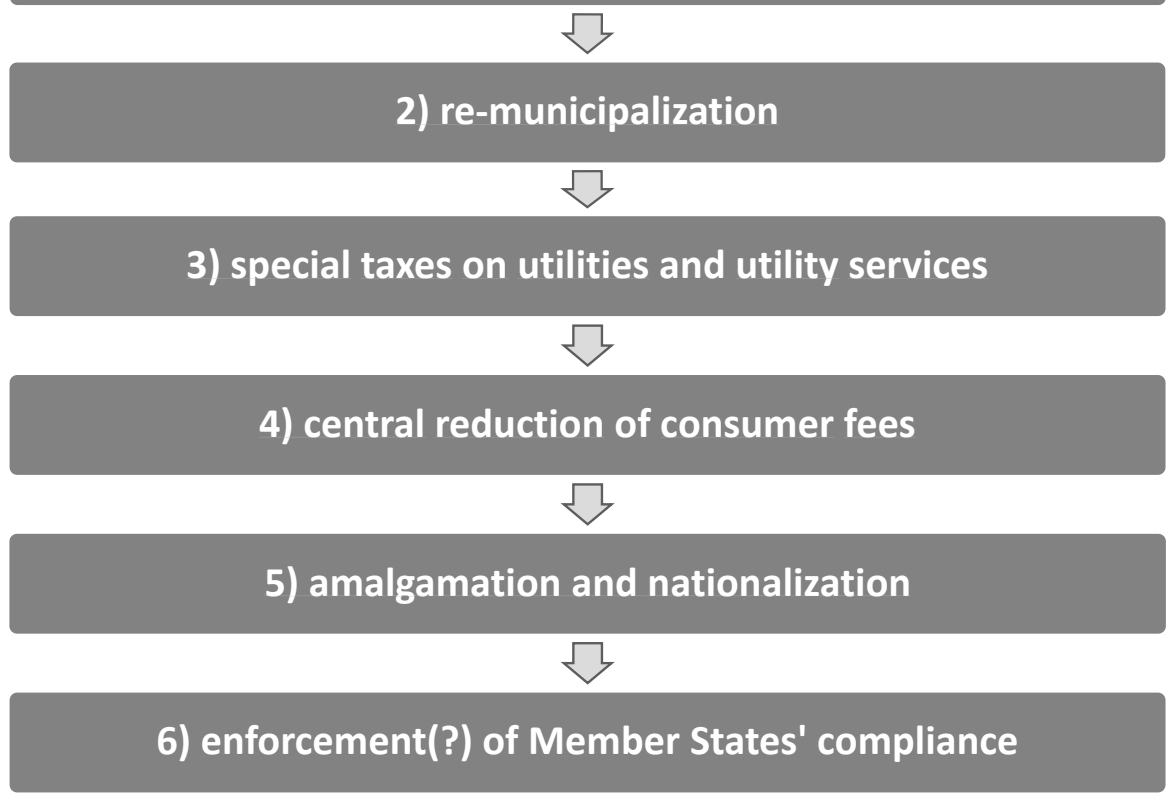

Source: Author

The brief understanding of the 'EU law reading' of Figure 1 is as follows.

i) From 2010, as already mentioned, there is a tendency in Hungary for larger local governments to acquire the majority of shares in companies being in charge of public utility service provision. In the name of 'transparency', sector law issued by the central government also assisted that process of strengthening public ownership in entities operating under private law. (The EU has no voice here as, under Article 345 TFEU, EU law does not concern the rules in Member States governing the system of property ownership.) In addition, these companies were also entrusted with exclusive rights by Hungarian local governments to fulfil certain municipal public service obligations (see point ii. in Ch. 6 above). As was already explained, EU law allows a wide discretion for Member States in choosing their instruments (granting exclusive rights among them ${ }^{14}$ ) for the operation of SGEls. Case-law of the ECJ also confirm that exclusive rights which restrict or even exclude competition in the internal market are not incompatible with EU law if they are necessary to ensure the performance of PSO assigned to the company concerned.

ii) The concept of 'in-house' refers to the implementation of re-municipalisation which involves providing services (which can be operated under market rules) directly by public means 'in house' instead of contracting with pri-

14 See especially Article 106 TFEU and relevant secondary legislation. 
vate economic operators. However, the provisions of the EU public procurement directives did not apply to 'in-house operation'. ECJ case-law also made clear that Member States were not precluded from adopting rules which enable public undertakings to provide public services without being subject to the public procurement regime laid down by these directives. The Altmark decision (and subsequent Commission communications) also assisted this 'leniency-direction' in EU public procurement law.

iii) Then, as explained in point ii. Ch. 6, special taxes were levied on public utility sector. Although EU state aid rules generally prohibit tax burden imposed on undertakings in a selective way (Article 107 TFEU), the 'escape routes' in the regime can save Member States from the application of these general prohibitions. ${ }^{15}$ Moreover, the tax on the utility network lines was originally imposed as a 'crises tax', which is a measure to reduce the negative effects of the global financial and economic crisis of 2008. As it is clear from its communications ${ }^{16}$ the Commission shows more understanding towards such initiatives and more flexibility in assessing the compatibility of national measures with EU competition rules.

iv) This process was followed by cutting utility fees (point iii. Ch. 6) by the central government making use of the regulatory competence granted by EU secondary law to Member States. Though price cap is one of the most serious interventions into market trends, the protection of household consumers ('Hungarian families') seemed to be a good argument against EU rules, especially under the authorisation given by the revised consumer protection clauses of the latest electricity and gas directives, ${ }^{17}$ and in light of the ECJ's Federutilityjudgment (C-265/08, ECLI:EU:C:2010:205).

v) The next step is nationalisation, i. e. the acts of the Hungarian Parliament not allowing to acquire the majority of ownership for private market participants in companies entrusted by public service provision. Here, Article 345 TFEU also supports Member States in escaping from their general obligations EU internal market and competition rules. The result of this policy is to redistribute shares in large service providing companies through getting the entire (or at least almost) $100 \%$ of the property in them in order to guarantee the full ownership rights for the government.

vi) Even if the EU law compatibility of the above measures may be called into question, the (de facto!) enforceability of the assumed infringement cannot be taken for granted. The effective protection of foreign undertakings' rights, who, as a result of the above process, were excluded from the market, cannot be ensured by the so-called infringement procedure (Art. 258 TFEU) and preliminary rulings (Art. 267 TFEU) as both of them take very often years to reach the final decision in the case. This long period of time is perfectly enough to reach the targeted market result of the national le-

15 See e.g. state subsidies saved by the application of Article 107(3)(b) TFEU.

16 As an example, see the '2008 Banking Communication' (OJ C 270, 25.10.2008, p. 8).

17 See Article 3(7) of Directive 2009/73/EC and Article 3(3) of Directive 2009/72/EC. 
gislator (the case of the Hungarian gambling market or reorganisation of the voucher system clearly justifies this statement). ${ }^{18}$

\subsection{Indirect Impacts}

There are also indirect effects of the official Hungarian public utility policy. Firstly, infringement procedures by the European Commission are taking place, because consumers' prices are defined by the ministry instead of the regulatory authority. In addition, specific taxes, like a tax on the length of pipe networks and energy transaction fees must not be calculated as an accepted cost.

Secondly, competition is also under attack. There are different prices for inhabitants and undertakings, which appears to be discrimination. Newly established huge state owned enterprises are in better position in tenders, avoiding formal public procurement processes. Several antitrust procedures are initiated because of this reason. Although keeping state aid rules are also questioned, there are less of these kind of disputes in European institutions.

Thirdly, international investment disputes are taking place, because semi-nationalization procedures under the new state owned property act and the actions of municipalities and the national state are questioned by private, especially foreign investors.

Fourthly, an indirect effect has been highlighted. Charges in the global market of the energy sector decreased, until the Hungarian government froze prices at a static level.

Fifthly, the PR and propaganda of the government focuses on the cutting of charges in the utility sector. It is one of the key issues of the campaign called 'The Hungarian reforms are working!' The most important figures with regards to the savings are obliged to be put on receipts sent to owners of dwellings monthly. This policy has been an important strategy of the national government since the beginning of 2013.

Sixthly, some sector providers have become bankrupt, in such areas as chimney sweeping, as well as many waste companies. In these cases, the national authority of civil defence becomes responsible for fulfilling public tasks, completely neglecting market actors.

\section{Conclusion}

All in all, according to independent lawyers, the legality deficit is quite serious in general in this situation either in the economic or political field. The tactics of the government have been realized mostly with 'success', because legal procedures are long-term, i.e. 4-6 years are needed, while advantages are realized in financial and interest-based power games. The price of it is to be paid by the public as a whole.

18 See the ECJ judgments in cases C-98/14, Berlington, EU:C:2015:386 and C-179/14, Commission v. Hungary, ECLI:EU:C:2016:108, as well as Varju and Papp (2016) for more details. 
As has already been proved, it is difficult in this case to term the actions of the government 'reforms', because the focus of the measures is more the reassessment of former preferences rather than improvement as such. As Prime Minister Viktor Orbán said in his speech at the national celebration on 15 March 2016, 'our results cannot be measured only with utilization, but the totality should be our preference'.

That is why 'renewal' is a more preferred term of the official PR, supplemented together with reforms, instead of particular sector policies. However, the phrase 'renewal' is substituted with the more neutral term of reassessment in the figure prepared by our investigation. The anticipated far-reaching objectives are very much interest-based, including economic interests of natural (national) monopolies. Comparing anticipated and non-anticipated aims we can conclude that the advantages of the intended effects are distributed to particular social and economic groups, while disadvantages are placed upon others.

In the above analysis, we identified a six-element process (amalgamation and transformation are forced by sector laws - re-municipalization - special taxes on utilities and utility services - central reduction of consumer fees - amalgamation and nationalization - problems in effective enforcement of Member States' compliance) which is able to change completely the market conditions for providing public utility services in an EU Member State. These actions investigated do not seem to be simply a package of intervention in order to achieve political aims, because - as we have proved - the development of EU law allows recently different (mis)understandings for the influence of the EU market rules from the side of the state (instead of the 'public' as such). It is also indicated by the analysis that EU rules are able to focus only on individual elements, but cannot serve as effective instruments against the whole (six-element) process of the change in the national 'public service regime'. According to our research, at least we are sure to state that as a result of the implementation of utility policies recently in Hungary, service levels did not improve. So, the reform rhetoric is not working in these circumstances, because the orientation of changes is clearly out of the question of public service performance. However, measures examined above run completely counter to the spirit of the original intention of the founders of the integration, and recent changes in EU law do not seem to raise unavoidable obstacles to such cases. 


\section{References}

Bauby, P. (2011). From Rome to Lisbon: SGls in Primary Law. In E. Szyszczak, J. Davies, M. Andenæs and T. Bekkedal, eds., Developments in Services of General Interest. The Hague: T.M.C. Asser Press, pp. 19-36.

Bauby, P. and Similie, M. (2014). Europe. In UCLG (United Cities and Local Governments), GOLD III. (Third Global Report on Local Democracy and Decentralization) Basic Services for All in an Urbanizing World. Abingdon: Routledge, pp. 94-131.

Bauby, P. and Similie, M. (2016a). What Impact Have the European Court of Justice Decisions. Had on Local Public Services? In I. Kopric, G. Marcou, and $\mathrm{H}$. Wollmann, eds., Public and Social Services in Europe. From Public and Municipal to Private Sector Provision. Basingstoke: Palgrave Macmillan, pp. 27-40.

Bauby, P. and Similie, M. (2016b). The European Union's State aid rules and the financing of SGEls' tasks. (Manuscript).

Białecki, I., Jakubowski, M. and Wiśniewski, J. (2017). Education policy in Poland: The impact of PISA (and other international studies). European Journal of Education, 52(1), pp. 167-174.

Bird, R. M., Ebel, R. D. and Wallich, C. E. (eds.) (1995). Decentralization of the Socialist State: Intergovernmental Finance in Transition Economies. Washington: The World Bank.

European Commission (EC). Implementing the Community Lisbon programme: Social services of general interest in the European Union. EC Communication No. COM (2006) 177 final.

Gajduschek, G., Horváth T. M. and Jugovits, K. (2017). Hungarian Public Administration: Last Thirty Years, Waves in the Story. In P. Kovač and M. Bileišis, eds., Public Administration Reforms in Eastern European Union Member States: Post-Accession Convergence and Divergence. Ljubljana, Vilnius: University of Ljubljana Faculty of Administration, Mykolas Romeris University Lithuania, pp. 237-301.

Hajnal, G. (2014). Unorthodoxy at work: An assessment of Hungary's post-2010 governance reforms. In Government vs. Governance in Central and Eastern Europe: from Pre-Weberianism to Neo-Weberianism. Bratislava: NISPAcee PRESS [CD-ROM], p. 26. At <www.researchgate.net/profile/Hajnal_Gyoergy/ publication/273447223/>, accessed 1 May 2017.

Hajnal, G. and Rosta, M. (2016). A new doctrine in the making? Doctrinal Foundations of Sub-National Governance Reforms in Hungary (2010-2014). Administration and Society, 28 January 2016.

Hall, D. (2012). Re-Municipalising Municipal Services in Europe. Greenwich: Public Services International Research Unit (PSIRU). A report commissioned by the European Federation of Public Service Unions (EPSU). Business School, University of Greenwich, p. 29. At <www.psiru.org>, accessed 19 September 2013.

Hancher, L. and Larouche, P. (2011). The Coming of Age of EU Regulation of Network Industries and Services of General Economic Interest. In P. Craig and G. de Búrca, eds., The Evolution of EU Law. Oxford: Oxford University Press, pp. 743-782.

Horváth, T. M., (ed.) (2002). Decentralization: Experiments and reforms. Budapest: Local Government and Public Service Reform Initiative, Open Society Institute. 
Horváth, T. M. (2016). From Municipalisation to Centralism: Changes in the Hungarian Local Public Service Delivery. In I. Kopric, G. Marcou, and H. Wollmann, eds., Public and Social Services in Europe. From Public and Municipal to Private Sector Provision. Basingstoke: Palgrave Macmillan, pp. 185-199.

Horváth, T. M. and Péteri, G. (eds.) (2001). Navigation to the market: regulation and competition in local utilities in Central and Eastern Europe. Budapest: Local Government and Public Service Reform Initiative, Open Society Institute.

Klasse, M. (2013). The Impact of Altmark: The European Commission Case Law Responses. In E. Szyszczak and J. W. van de Gronden, eds., Financing Services of General Economic Interest: Reform and Modernization. The Hague: T.M.C. Asser Press, pp. 35-51.

Krajewski, M. (2011). Grundstrukturen des Rechtsöffentlicher Dienstleistungen [Fundamental principles of the law of public services]. Heidelberg: Springer

Kuhlmann, S. and Wollmann, H. (2011). The Evaluation of Institutional Reforms at Sub-national Government Levels: A Still Neglected Research Agenda. Local Government Studies, 37(5) pp. 479-494.

Marćou, G. (2016). The Impact of EU Law on Local Public Service Provision: Competition and Public Service. In I. Kopric, G. Marcou, and H. Wollmann, eds., Public and Social Services in Europe. From Public and Municipal to Private Sector Provision. Basingstoke: Palgrave Macmillan, pp. 13-26.

Pigeon, M., McDonald, D. A., Hoedeman, O. and Kishimoto, S. (eds.) (2012). Remunicipalisation: Putting Water Back into Public Hands. Amsterdam: TNI (Transnational Institute).

Prosser, T. (2005). The Limits of Competition Law: Markets and Public Services. Oxford: Oxford University Press.

Ross, M. (2000). Article 16 E.C. and Services of General Interest: From Derogation to Obligation? European Law Review, 25(1), pp. 22-38.

Rusche T. A. (2013). The Almunia Package: Legal Constraints, Policy Procedures, and Political Choices. In E. Szyszczak and J. W. van de Gronden, eds., Financing Services of General Economic Interest: Reform and Modernization. The Hague: T.M.C. Asser Press, pp. 99-124.

Schweitzer, H. (2012). Services of General Economic Interest. In M. Cremona, ed., Market Integration and Public Services in the European Union. Oxford: Oxford University Press, pp. 12-63.

Sauter, W. (2014). Public Services in EU Law. Cambridge: Cambridge University Press.

Szyszczak, E. (2017). Recent Case Law: Altmark and Local and Regional Subsidies to Public Services. Paper presented at the EU Judicial Training "The Law and Economics of State Aid Before National Courts" UCD Dublin, 7-8 July 2017 (Manuscript).

Tsekos T. N. and Triantafyllopoulou A. (2016). From Municipal Socialism to the Sovereign Debt Crisis: Local Services in Greece 1980-2015. In Public and Social Services in Europe. From Public and Municipal to Private Sector Provision. In I. Kopric, G. Marcou, and H. Wollmann, eds., Public and Social Services in Europe. From Public and Municipal to Private Sector Provision. Basingstoke: Palgrave Macmillan, pp. 135-149.

Varju, M. (2013). A közszolgáltatások szabályozása az Európai Unióban

[Regulation of Public Services in the European Union]. In T. M. Horváth, ed., 
Kilengések. Közszolgáltatási változások [Swings. Changes in Public Service Delivery]. Budapest: Dialóg Campus, pp. 103-137.

Varju M. and Papp M. (2016). The crisis, national economic particularism and EU law: What can we learn from the Hungarian case? Common Market Law Review, 53(6), pp. 1647-1674.

Vedder H. and Holwerda M. (2013). The European Courts' Jurisprudence After Altmark; Evolution or Devolution? In E. Szyszczak and J. W. van de Gronden, eds., Financing Services of General Economic Interest: Reform and Modernization. The Hague: T.M.C. Asser Press, pp. 53-67.

Water Remunicipalisation Tracker. At <http://www.remunicipalisation.org>, accessed 19 September 2013.

Wollmann, H. (2003). Evaluation in Public Sector Reform: Concepts and Practice in International Perspective. Cheltenham: Edward Elgar.

Wollmann, H. and Marcou G. (eds.) (2010) The Provision of Public Services in Europe: Between State, Local Government and Market. Cheltenham: Edward Elgar. 


\section{Annex 1. Fundamental provisions of EU primary law on SGEls}

\section{FUNDAMENTAL PROVISIONS OF EU PRIMARY LAW ON SGEIS \\ Article 14 TFEU}

Without prejudice to Article 4 of [TEU] or to Articles 93, 106 and 107 [TFEU], and given the place occupied by services of general economic interest in the shared values of the Union as well as their role in promoting social and territorial cohesion, the Union and the Member States, each within their respective powers and within the scope of application of the Treaties, shall take care that such services operate on the basis of principles and conditions, particularly economic and financial conditions, which enable them to fulfil their missions. The European Parliament and the Council [...] shall establish these principles and set these conditions without prejudice to the competence of Member States [...] to provide, to commission and to fund such services.

\section{Article 102 TFEU}

Any abuse by one or more undertakings of a dominant position within the internal market or in a substantial part of it shall be prohibited as incompatible with the internal market in so far as it may affect trade between Member States.

\section{Article 106 TFEU}

1. In the case of public undertakings and undertakings to which Member States grant special or exclusive rights, Member States shall neither enact nor maintain in force any measure contrary to the rules [on competition] contained in the Treaties.

2. Undertakings entrusted with the operation of services of general economic interest or having the character of a revenue producing monopoly shall be subject to the rules contained in the Treaties, in particular to the rules on competition, in so far as the application of such rules does not obstruct the performance, in law or in fact, of the particular tasks assigned to them. The development of trade must not be affected to such an extent as would be contrary to the interests of the Union.

\section{Article 107 TFEU}

[...] any aid granted by a Member State or through State resources in any form whatsoever which distorts or threatens to distort competition by favouring certain undertakings or the production of certain goods shall, in so far as it affects trade between Member States, be incompatible with the internal market.

\section{Article 345 TFEU}

The Treaties shall in no way prejudice the rules in Member States governing the system of property ownership.

\section{Protocol (No 26) on Services of General Interest annexed to TFEU Article 1}

The shared values of the Union in respect of services of general economic interest within the meaning of Article 14 [TFEU] include in particular:

the essential role and the wide discretion of national, regional and local authorities in providing, commissioning and organising services of general economic interest as closely as possible to the needs of the users; [...]

\section{The Charter of Fundamental Rights of the European Union, Article 36 Access to services of general economic interest}

The Union recognises and respects access to services of general economic interest as provided for in national laws and practices, in accordance with the Treaty establishing the European Community, in order to promote the social and territorial cohesion of the Union. 
Tamás M. Horváth, Ildikó Bartha

Annex 2. Trends of Consumer Price Indexes according to consuming in particular public services (2003-2012)

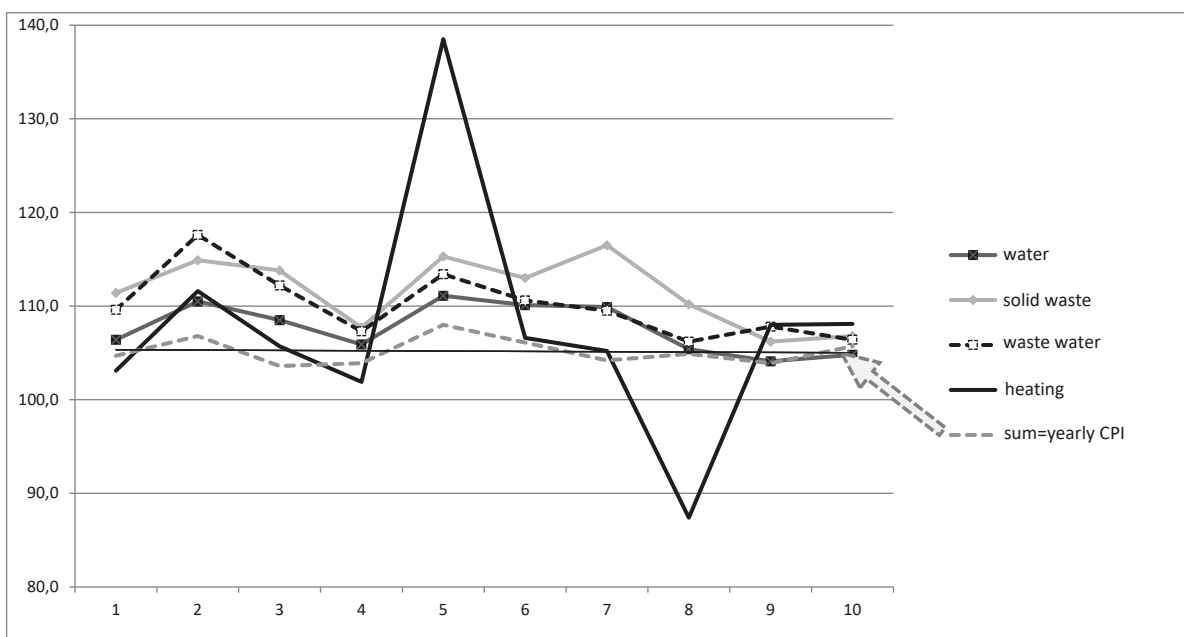

Source: STADAT COICOP indexes, 2013 


\section{Annex 3. Municipal corporations and field of re-municipalisation (Budapest Urban Management Centre cPlc)}

The structure of the Budapest Urban Management Center cPIc

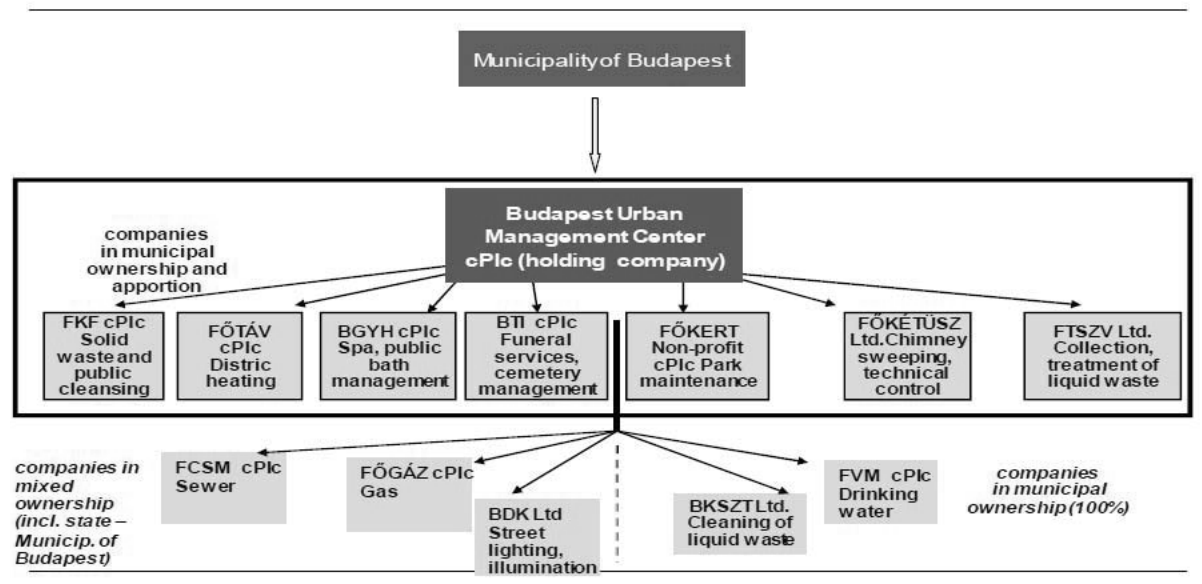

Source: Budapest City Council 